\title{
Nutritional Aspects of Two Widely Consumed Wild Edible Mushrooms in Jordan
}

\author{
Ahmad Mohamad Almomany \\ Royal Botanic Garden, Amman-Tell ar Rumman 11910, Jordan
}

Received: December 12, 2012 / Accepted: March 19, 2013 / Published: June 30, 2013.

\begin{abstract}
Two wild mushrooms frequently consumed in Jordan were collected form Jordan forests in spring 2012. Each sample was studied in the lab by taking measurements on the morphological structures of the cap, stem, and recording gill's color, shape and dimensions. Also smell and taste for each fruiting structure were taken in consideration. Spore print for each sample was also defined. Spores of each mushroom were microscopically tested and measured. These mushrooms were identified as Pleurotus eryngi and Tricholoma terreum. The two mushrooms were evaluated for their physical properties, chemical and mineral composition. Contents of $\mathrm{Ca}, \mathrm{Na}, \mathrm{K}, \mathrm{Zn}, \mathrm{Mn}, \mathrm{Cu}, \mathrm{Fe}$ and $\mathrm{Mg}$ were determined. For each mushroom species two mixed samples were analyzed. Nitrogen content was detected with Kjeldahl method and protein content (\%) was calculated by multiplying nitrogen content with the factor 4.38. The highest protein content calculated on oven dry weight basis was found in Pleurotus eryngi which was around $30.6 \%$, while Tricholoma terreum contained lowest protein content (17.4\%). Pleurotus eryngi accumulated trace elements at high ratios as for P, Ca and Na $0.99 \%, 0.65 \%$ and $0.57 \%$ respectively while Tricholoma terreum contained more K (5.1\%) than the other wild mushroom. Total soluble carbohydrates (50.8\%), crude fiber (13.4\%) and ash (12.2\%) percentages were higher in Tricholoma terreum than in Pleurotus eryngi.
\end{abstract}

Key words: Mushroom, Pleurotus, Tricholoma, protein, fat, ash, minerals.

\section{Introduction}

More than 2,000 species of mushrooms exist in nature but only approximately 25 species are intensively cultivated for commercial purposes, on ground or wood and utilising particular environmental and nutritional conditions [1]. Mushrooms are well recognized for their flavor and nutritional values [2]. Fungi are known as a good source of phytosterols [3]. The nutritional interest in phytosterols derives from the fact that they reduce cholesterol absorption, thereby having the capacity to reduce plasma cholesterol with no side-effects [4]. The consumption of wild edible mushrooms is increasing due to a good content of proteins, dietary fibre and trace elements [5]. Both wild and cultivated mushrooms are good sources of vitamins and proteins. Chanterelles and king bolete

Corresponding author: Ahmad Mohamad Almomany, Ph.D., professor, research fields: fungi and fungal disease control. E-mail: amomany@royalbotanicgarden.org. have been reported to contain significant amounts of natural vitamin $\mathrm{D}_{2}$ compared with cultivated mushrooms that had a low content. Canned samples of Agaricus bisporus were slightly lower in ergosterol and vitamin $\mathrm{D}_{2}$ compared to fresh samples [6]. Spawn type and strain influenced the yield of Agaricus bisporus produced on non-composted and spent mushroom compost [7]. The cultivated mushroom has received the attention of several investigators mainly for extending its shelf life and quality [8]. There are a few mushroom farms in Jordan, and their production covers only a small portion of the market but the canned products of mushroom are available in Jordan. Many wild mushroom species are found in Jordan, out of which 56 species have been identified for their toxicity [9, 10]. The lack of information about nutritional value and chemical compositions of Jordan wild mushrooms lead us to this investigation. The objective of this research was to extend knowledge on nutritional quality and 
chemical composition of two edible wild mushrooms widely consumed in Jordan.

\section{Materials and Methods}

\subsection{Sample Collection and Preperation}

Two mature fresh mushroom samples were collected during February 2012 from Jordan forests in Tell ar Rumman (Royal Botanic Garden) and Thugret Asfoor-Jarash. The mushrooms were growing in pine tree forests and one of them was found in Tell ar Rumman where Ferulla commune was growing also near pine trees. Each fresh sample was a mixed sample and $2 \mathrm{~kg}$ in weight, carefully cleaned from soil and organic debris, washed with distilled water, drained and thinly sliced to have a representative sample. For each mushroom three samples were dried in electrical radiant heat oven (Binder, Germany) at $70{ }^{\circ} \mathrm{C}$ for $72 \mathrm{~h}$ until the weight was constant to calculate the moisture content, then dried at $102{ }^{\circ} \mathrm{C}$ for $8 \mathrm{~h}$ for further analysis. The dried material was ground to pass through a $1 \mathrm{~mm}$ mesh sieve. They were mixed thoroughly and kept in plastic bags and stored in a freezer at $-4{ }^{\circ} \mathrm{C}$ until used for mineral investigations [11]. The specimens were examined in the laboratory and identified according to [12-14]. Each sample was studied in the laboratory by taking measurements of the cap, stem, and recording gills color, shape and dimensions. Also smell and taste for each fruiting structure were taken in consideration. Spore print for each fresh mature sample was also defined by laying the fruiting body over glass sheath and covered it overnight with a glass beaker to avoide drying [14]. Spores of each mushroom were microscopically studied and photographed by recording the shape, colour and size of more than twenty arbitrary choosen spores.

Mineral contents of $\mathrm{Ca}, \mathrm{Na}$, and $\mathrm{K}$, were determined by using a flame photometer (JENWAY, UK) and phosphorus content was determined according to AOAC procedure [15] by using spectrophotometer (UVIKON810, Switzerland). For each mushroom species, the whole nutritional analysis was replicated three times. To determine crude protein percentage, nitrogen content was determined by Kjeldahl method (LabConco, UK) according to [15] and [11] and protein content (\%) was calculated by multiplying nitrogen content with the factor 4.38 according to Ref. [16]. Moisture, crude fiber, crude fat and ash contents were determined according to Ref. [15]. Ash percentage was determined by heating the dried sample in muffle furnace (Naber, Germany) at $550-600{ }^{\circ} \mathrm{C}$ for $8 \mathrm{~h}$ until the color of the treated substance become gray and $6 \mathrm{~N}$ $\mathrm{HCl}$ was added to test for complete ashing by dissolving the material very well. Fat was determined by petroleum ether extraction using Foss Soxtec 2045, (Switzerland) system for $16 \mathrm{~h}$. The material was boiled in $1.25 \% \mathrm{H}_{2} \mathrm{SO}_{4}$ for 45 min then in $1.25 \% \mathrm{NaOH}$ for another $45 \mathrm{~min}$, and then dried to determine crude fiber percentage using Ankom 220, USA system. The energy values were calculated as $\mathrm{Cal} / \mathrm{g}$ by using IKA-C5003-Werke, Germany system. Total carbohydrates were calculated by difference using the following equation: Total carbohydrates $=100-(\mathrm{g}$ moisture + g protein + g fat + g ash) [17].

\subsection{Statistical Analysis}

Statistical analysis of the data on protein, carbohydrate, crude fiber and fat, ash and moisture as well as for minerals contents were performed using SAS package at the Computer Center of the University of Jordan. The data were reported as means \pm SD for six determinations.

\section{Results and Discussion}

\subsection{Classification of Collected Mushrooms}

Pleuorotus eryngi (Sample No.1) was identified according to the following characteristics: Cap 4-12 cm across, convex to depressed in the center, whitish and the margins becoming toothed with age. Breaking of upper surface into large scales started from the center. Stem 20-60 mm $\times$ 7-25 mm with lateral to centric development. Flesh white in color. Gills are descending with stem and whitish-honey. Taste 
mushroomy and smell faint of crushed almonds when young. Spore print white creamy in color with cylindrical to narrowly kidney shaped spores and with prominent germ pore which varied from 10.2-13.8 $\times$ 4-6.5 $\mu$ (Fig. 1). Tricholoma terreum (Sample No.2) has a cap with 2-7 cm across, concave shaped, variable in color from brown to grey-brown. Later become flat with tattered and curled edges. Stem 20-60 × 10-15 cm, white and silky smooth. Flesh white in color and smell pleasant. Spore print white with elliptical to oval and smooth spores measuring 7.5-10 × 5-6.5 $\mu$ (Fig. 2).

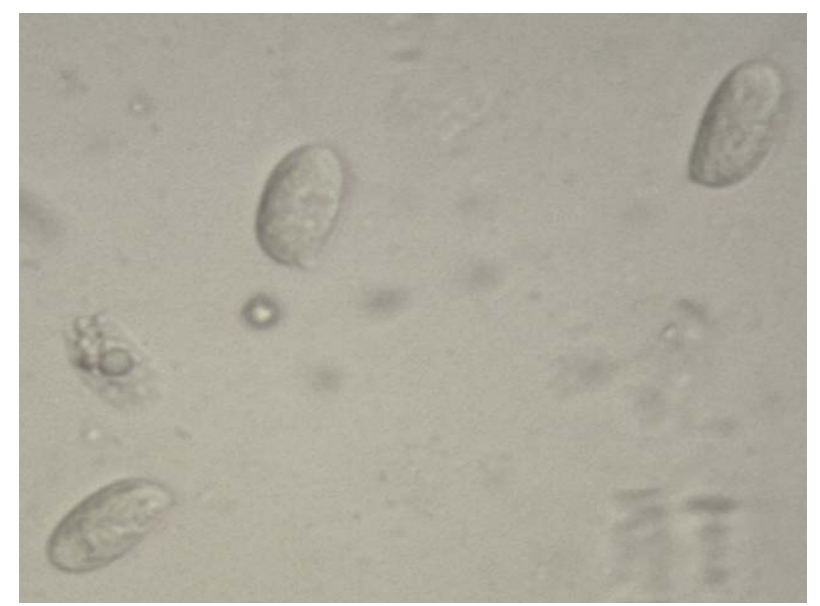

Fig. 1 Spores of Pleuorotus eryngi.

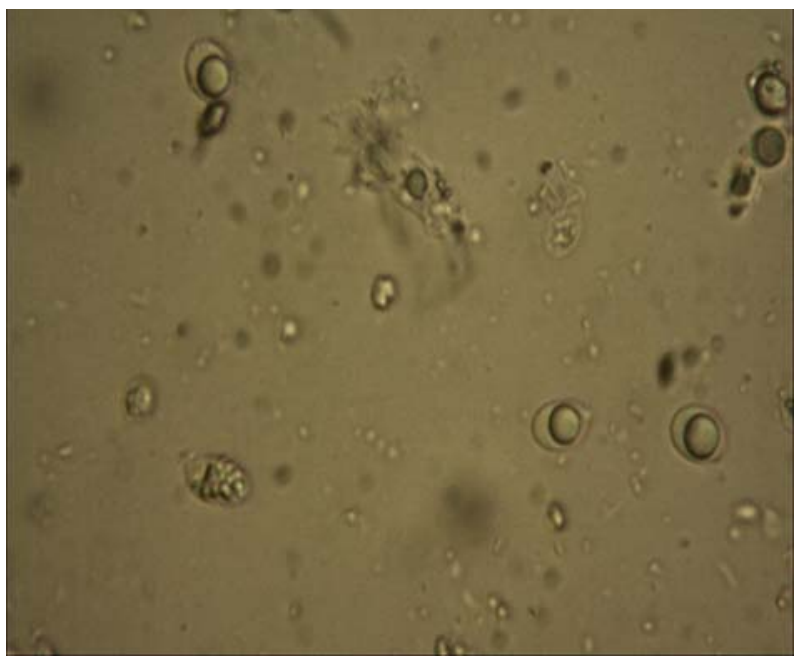

Fig. 2 Spores of Tricholoma tereum.

\subsection{Proximate Analysis of Mushrooms}

The highest and significantly different protein value (30.6\%) was found in the cultivated mushroom Pleurotus eryngi while Tricholoma tereum contained the lowest protein content (17.5\%) as shown in Table 1. There were significant differences amongst the two mushroom genera concerning protein content. According to Ref. [18] 72\%-83\% of the total nitrogen would be in the form of digestible protein. In the fruit body of edible mushrooms a large amount of nitrogen is actually present in non-protein compounds; due to urea, ninhydrin positive compounds and a high proportion of $\mathrm{N}$-containing chitin; hence the conversion factor of total nitrogen into crude protein is 3.45-4.38 [19, 20].

Normally crude protein correlation factor adopted for mushrooms in food composition tables was calculated using the conversion factor of $(\mathrm{N} \times 4.38)$. This would establish that mushrooms are relatively high in digestible proteins compared with vegetable foods. The corrected amino acid scores of two Tricholoma species were low compared with those of egg white but higher than those of many vegetable proteins [20]. However, it is known that the protein contents of mushrooms are affected by many factors, namely the type of mushrooms, the stage of development, the part sampled, level of nitrogen available and the location [21].Wild mushrooms were rich sources of protein (close to $16 \%$ of dry weight) and had low fat contents (5.7\%-6.6\%) making it an ideal snack material [20]. Both mushrooms contained the same percentage of crude fat while Tricholoma contained higher ash percentage than Pleurotus eryngi (12.3\%). This was reflected in containing low energy where the relation between energy and ash \% was reciprocally.

Table 1 Nutritional analysis of two wild Jordan mushrooms.

\begin{tabular}{lcclll}
\hline Mushroom name & Protein $\% \pm$ SD & Ash $\% \pm$ SD & Moisture $\% \pm$ SD & Crude fat $\% \pm$ SD & Crude fiber $\% \pm$ SD \\
\hline Pleurotus eryngi & $* 30.6 \pm 0.03$ & $9.5 \pm 0.04$ & $90.3 \pm 0.75$ & $5.8 \pm 0.00$ & $12.5 \pm 0.13$ \\
Tricholoma terreum. & $17.5 \pm 0.19$ & $12.3 \pm 0.08$ & $91.1 \pm 0.53$ & $5.9 \pm 0.02$ & $13.5 \pm 0.09$ \\
\hline
\end{tabular}

*Values are means of three determinations on dry weight basis. 
Table 2 Mineral composition of two wild Jordan mushrooms.

\begin{tabular}{lll}
\hline Mushroom name / element & Pleurotus eryngi \pm SD & Tricholoma terreum \pm SD \\
\hline Potassium (K), \% & $* 3.934 \pm 0.02$ & $5.125 \pm 0.05$ \\
Sodium (Na), \% & $0.57 \pm 0.06$ & $0.293 \pm 0.11$ \\
Calcium (Ca), \% & $0.652 \pm 0.00$ & $0.335 \pm 0.01$ \\
Phosphorus (P), \% & $0.992 \pm 0.01$ & $0.557 \pm 0.02$ \\
\hline
\end{tabular}

*Values are means of 3 determinations on dry weight basis.

Table 3 Carbohydrate and energy content of two wild Jordan mushrooms.

\begin{tabular}{lll}
\hline Mushroom Name / Element & Pleurotus eryngi \pm SD & Tricholoma terreum \pm SD \\
\hline Carbohydrate, \% & $* 41.5 \pm 0.21$ & $50.8 \pm 0.0 .16$ \\
Energy, Cal/g & $4554 \pm 1.05$ & $4295 \pm 1.14$ \\
\hline
\end{tabular}

*Values are means of three determinations on dry weight basis.

\subsection{Mineral Analysis}

The data on mineral analysis of the investigated mushrooms are shown in Table 2. Significant differences were observed between the two mushrooms. The highest $\mathrm{Na}, \mathrm{Ca}$, and phosphorus contents were found in Pleurotus eryngi. Care should be taken for substrate composition to avoid any buildup of any trace metals [21]. Tricholoma was good source for K while Pleurotus eryngi contained the lowest concentration. The explanation for the variation of mineral contents in the tested mushrooms might be due to genotypic effect [22]. Not only that but also the type of substrate used composted or non-composted, its composition and availability of its mineral contents, the absorptive capacity of the mushroom mycelia, age of the mushroom and the environment (water, temperature and humidity) have also prominent effects.

The highest carbohydrate content (50.8\%) was found in Tricholoma terreum and it was significantly different from Pleurotus eryngi but Tricholoma terreum contained less energy than Pleurotus eryngi because of high ash content in Tricholoma terreum (Table 3).

So it is necessary to use always fresh samples for any nutritional analysis. Mushrooms quality is influenced by the stage of development and pre- and post-harvest conditions. Post-harvest treatment with citric acid or hydrogen peroxide extended the shelf life of fresh sliced mushrooms [8]. On average, a serving (100 g) of mushrooms guarantees from $9 \%$ to $40 \%$ of the daily recommendation of dietary fibre [23]. Content of dietary fibre was high (approx. 45\% of dry matter) in two Tricholoma species [20].

\section{Conclusions}

The chemical composition and protein values of the two mushrooms clearly indicated that they provide key nutrients. Being a good source of protein and carbohydrate, they fall between most legumes and meat [24] and prove to be excellent foods that can be used in well- balanced diets for their low contents of fat and energy. Results have shown also that Pleurotus eryngi is a good source of energy, sodium, calcium, phosphorus and protein. No significant differences were obtained between the two wild mushrooms concerning crude fiber content.

\section{Acknowledgment}

The author is grateful to HRH Princes Basma bint Ali, the founder of the Royal Botanic Garden, Tell ar Rumman, Jordan for financial support of this work. The author also thanks Mr. E. Alkurdi, Department of Animal production, University of Jordan for his help in performing chemical analysis.

\section{References}

[1] U. Lindequist, T. Niedermeyer, D. Julıch, The pharmacological potential of mushrooms, Evidence-Based Complementary and Alternative 
Medicine 2 (2005) 285-299.

[2] W. Breene, Nutritional and medicinal value of specialty mushrooms, J. of Food Prot. 53 (1990) 883-894.

[3] P. Mattıla, P. Vaananen, K. Konko, H. Aro, T. Jalava, Basic composition and amino acid contents of mushrooms cultivated in Finnland, J. of Agr. and Food Chem. 50 (2002) 6419-6422.

[4] M. Shin, S. Rim, Y. Jang, D. Choi, S. Kang, S. Cho, The cholesterol-lowering effect of plant sterol-containing beverage in hypercholesterolemic subjects with low cholesterol intake, Nut. Res. 23 (2003) 489-496.

[5] R. Thimmel, R. Kluthe, The nutritional database for edible mushrooms, Ernahrung 22 (1998) 63-65.

[6] A. Teıchmann, P. Dutta, A. Staffas, M. Jagerstad, Sterol and Vitamin $D_{2}$ concentrations in cultivated and wild grown mushrooms: Effects of UV irradiation, Food Sci. and Tech. 40 (2007) 815-822.

[7] D. Mamıro, D. Royse, The ifluence of spawn type and strain on yield, size and mushroom solids content of Agaricus bisporus produced on non-composted and spent mushroom compost, Bioresource Tech. 99 (2008) 3205-3212.

[8] M. Brennan, G. Le Port, R. Gormley, Post-harvest treatment with citric acid or hydrogen peroxide to extend the shelf life of fresh sliced mushrooms, Lebensmittelwissenschaft und Tech. 33 (4) (2000) 285-289.

[9] A. Almomany, Biodiversity of wild mushrooms in Jordan, Royal Botanic Garden. Amman. 312 (2012) 37-45.

[10] R. Natour, A. Salhab, A. Almomany, E. Saba, Wild mushrooms in Jordan, Dirasat 19 (2) (1992) 47-60.

[11] A. Mshandete, J. Cuff, Proximate and nutrient composition of three types of indigenous edible wild mushrooms grown in Tanzania and their utilization prospects, African Journal of Food Agriculture Nutrition and Development (6) (2007) 1-16.

[12] D. Benjamin, Mushrooms: Poisons and Panaceas, A Handbook for Naturalists, Mycologists and Physicians, WH Freeman and Company, New York, 1995, p. 250.
[13] E. Gerhardt, Der grosse Pilz Fuehrer fuer Unterwegs, BLV Handbuch, Germany, 2008.

[14] R. Phillips, Mushrooms, A Comprehensive Guide with Over 1250 Detailed Photographs of Mushrooms and Other Fungi, Macmillan Books, London, 2006, p. 384.

[15] AOAC, Official Methods of Analysis, 16th ed., Arlington VA, USA, 1995.

[16] E. Crisan, A. Sands, Nutritional value, in: S.T. Chang, W.A. Hayes (Eds.), The Biology and Cultivation of Edible Mushrooms, Academic Press Inc, London, 1978, pp. 137-165.

[17] L. Barros, T. Cruz, P. Baptista, L. Estevinho, I. Ferreira, Wild and commercial mushrooms as source of nutrients and nutraceuticals, Food and Chemical Toxicology 46 (2008) 2742-2747.

[18] W. Lintzel, Über den Nährwert des Eiweisses essbarer Pilze, Chemiker Zeitung (Nutritional value of proteins of edible mushrooms, Chemical Journal) 67 (1943) 333-339.

[19] A. Braaksma, D. Schaap, Protein analysis of the common mushroom Agaricus bisporus, Post Harvest Biology and Technology 7 (1996) 119-127.

[20] V. Diez, A. Alvarez, Compositional and nutritional studies on two wild edible mushrooms from northwest Spain, Food Chem. 75 (2001) 417-422.

[21] L. Cocchi, L. Vescovi, L. Petrini, O. Petrini, Heavy metals in edible mushrooms in Italy, Food Chem. 98 (2006) 277-284.

[22] P. Kalac, L. Svoboda, A review of trace element concentrations in edible mushrooms, Food Chem. 69 (2000) 273-281.

[23] P. Manzi, A. Aguzzi, P. Pizzoferrato, Nutritional value of mushrooms widely consumed in Italy, Food Chem. 73 (2001) 321-325.

[24] FAO/WHO, Protein quality evaluation, Report of the Joint FAO/WHO Expert Consultation, Food and Nutrition Paper No. 51, Food and Agriculture Organization and the World Health Organization, Rome, Italy, 1989. 